Proceedings

\title{
The Role of Sex and Family Status on the Relationship between Exposition to Violence and Child-to-Parent Violence
}

\author{
Miriam Junco-Guerrero ${ }^{1}$, Ana Ruiz-Fernández ${ }^{1}$ and David Cantón-Cortés ${ }^{1, *}$ \\ University of Malaga; M.J.: miriamjunco97@gmail.com; A.R.: anruizf@hotmail.com \\ * Correspondence: david.canton@uma.es
}

Publisher's Note: MDPI stays neutral with regard to jurisdictional claims in published maps and institutional affiliations.

\section{(c) (i)}

Copyright: $\odot 2021$ by the authors. Submitted for possible open access publication under the terms and conditions of the Creative Commons Attribution (CC BY) license (http://creativecommons.org/licenses/by/4.0/).

\begin{abstract}
The objective of this study was to analyze the relationship of the exposition to violence and justification of violence with child-to-parent violence (CPV) towards father and mother. Sample comprised 748 high school students (413 male and 335 female), between 13 and 20 years old. Childto-Parent Aggression Questionnaire (CPAQ) was employed to assess CPV. Exposition to violence in high school, home, street and television was assessed using the Violence Exposure Questionnaire (VEQ), whereas expostion to violence in videogames was assessed through a questionnaire prepared by the authors. Justification of violence was analyzed using the Justification of Violence subscale of the Irrational Beliefs Scale for Adolescents (ECIA).

Regarding violence towards mother, results showed that, in the case of female participants, there was a significant relationship with exposition to violence at street, home and an inverse relationship with videogames, as well as with violence justification, whereas in the case of male participants there was a significant relationship with the same variables except violence in videogames. Converserly, with regard to violence towards father, there was a significant relationships with violence at home and violence justification in the case of females, as well as with violence at home and street and violence justification in the case of male participants.

With regard to the role of the type of family, in the case of non-divorced families there was a significant relationship with exposition to violence at street, home and an inverse relationship with videogames, as well as with violence justification, whereas in the case of divorced families the only significant variable was violence justification. Finally, with regard to violence towards father, there was a significant relationships with violence at high school, street and home, along with violence justificacion in the case of non-divorced families, as well as violence at street and violence justification in the case of divorced families.

The present study shows the role of participant sex and family status the relationship of exposition to violence and violence justification with CPV violence. These findings indicate the importance of taking into account those variables in preventing violence towards parents.
\end{abstract}

Keywords: Child-to-parent violence; High school; Violence exposition; Videogames; Family; Television

\section{Introduction}

Child-to-parent violence (CPV) or parental abuse is a type of intra-family violence, defined as "repeated behaviors of physical, psychological (verbal or non-verbal) or economic violence, directed at parents, or those adults who take their place" [1] (p. 220).

Prevalence data of child-to-parent violence are not conclusive. Gallaguer [2] found that the international prevalence of this type of violence ranges between $10 \%$ and $18 \%$. In 
Spain, some studies establish that between $8.2 \%$ and $9 \%$ of adolescents admit having exercised physical violence against their parents, and between $13.1 \%$ and $14 \%$ psychological violence [3].

Furthermore, some studies suggest that, as is occurring with gender violence [4], CPV rates are increasing due to the confinement situations provoked by the current COVID-19 pandemic [5]. As the outbreak spread across the World, nations began to shut down gatherings, close schools, and confine people to their homes. As a consequence, a significant percentage of parents and practitioners have reported an increase in violent episodes during lockdown. Thus, it is important to analyze the consequences of the current pandemic for families experiencing CPV.

Regarding gender differences in violence against parents, previous research concludes that this is a type of violence exercised by both boys and girls [6]. However, there are differences regarding the type of violence exercised, physical violence being more frequent in the case of boys and psychological violence in the case of girls [7].

Research shows different family characteristics that could be considered as risk factors for the commission of violence towards parents [8]. CPV has been associated with exposure to violence, including being a victim or witness of violent behavior and can occur in different settings (school, home, street, television). Some studies show that violence between parents or by parents towards children is related to CPV [9]. Other studies have associated child-to-parent violence with violence at school, showing that observing and/or being a victim of violence at school is positively related to the commission of violent behavior by children [10].

Exposure to violence can also occur through violent video games. Greitemeyer and Mügge [11] found that violent video games are positively related to engaging in aggressive behaviors. Some authors have proposed that, together with television, video games have an influence on CPV commission [12]. However, studies in this regard are not conclusive, since some research shows an absence of connection between general violence and video games [13].

Finally, the justification of violent behaviors has also been considered as a risk factor for the commission of CPV. For example, Calvete [14] found an association between the justification of violence and problematic behaviors. Other studies have shown that exposure to violence at home predicts behavioral problems, and these are mediated by the justification of violence [15].

In this sense, the objective of this study is to evaluate a series of variables as risk factors in the prediction of child-to-parent violence. To do this, we will analyse what is the relationship between the variables of family status (divorced and non-divorced families), the sex of the aggressor and the exposure and justification of violence, with exercising child-parental violence.

\section{Method}

\subsection{Participants}

The sample of the present study comprised 748 high school students (413 male and 335 female) aged between 13 and 20 years old.

\subsection{Instruments}

In order to collect the socio-demographic data of the participants, a set of questions were asked concerning age, sex, and marital status of their parents.

Child-to-Parent Aggression Questionnaire (CPAQ) [16]. Evaluates CPV through 22 parallel ítems, concerning the father and the mother, describing psychological aggressions, physical assaults and financial violence.

Violence Exposure Questionnaire (VEQ) [17]. Evaluates violence exposure through 21 items assembled in 4 blocks according to the context (high school, home, street and television). 
Exposition to violence in videogames. Self-made questionnaire in which participants have to indicate the names of the videogames they have played in the last 6 months, as well as the names of the videogames they have played the most in their entire lives.

Irrational Beliefs Scale for Adolescents (ECIA) [18]. Evaluates justification of violence through 12 items assambled in 6 irrational beliefs. Only violence justification was taken into account in the present study.

\subsection{Statistical Analysis}

Statistical analyses were based on hierarchical multiple regressions (with a probability for input $\mathrm{F}$ of $\mathrm{p}=.05$ and output of $\mathrm{p}=.10$ ), and were performed with IBM SPSS 26 (Statistical Package for the Social Sciences) version 20. Following protocol, centered scores were used as a means of addressing the problem of multicollinearity [19].

\section{Results}

First, the percentage of participants who committed severe assaults on their parents was calculated. The percentages of participants who reported threatening behavior, insults, blackmail, doing something to annoy their parents, disobeying an important order, or taking money without their permission on more than 6 occasions were considered severe psychological or economic assaults. To assess severe physical aggression, the percentage of cases reporting physical assault on at least 3-5 occasions was considered. Concerning severe physical aggression, $2.3 \%$ of the participants acknowledged that they had committed it against their mother, and $1.8 \%$ against their father. Twenty five percent acknowledged having committed serious psychological assaults against their mother and $21 \%$ against their father. Finally, concerning economic violence, $9.4 \%$ had committed it against their mother, and $7 \%$ against their father.

Next, 8 independent multiple regression analyses were carried out to determine the variables related to CPV towards mothers and towards fathers, as a function of participant's sex (male and female) and family status (intact family and divorced family).

Regarding violence towards mother (table 1), results showed that, in the case of female participants, there was a significant relationship with exposition to violence at street, home and an inverse relationship with videogames, as well as with violence justification. In the case of male participants there was a significant relationship with the same variables except violence in videogames. Conversely, with regard to violence towards father (table 2), there was a significant relationship with violence at home and violence justification in the case of females, as well as with violence at home and street and violence justification in the case of male participants.

Table 1. CPV towards mother as a function of participant's sex.

\begin{tabular}{|c|c|c|c|c|}
\hline Variable & Adjusted $R^{2}$ & $F \Delta$ & Beta & $t$ \\
\hline Male & 0.239 & $19.46^{* * *}$ & & \\
\hline Family status & & & -0.02 & -0.54 \\
\hline $\begin{array}{l}\text { Violence at high } \\
\text { school }\end{array}$ & & & 0.10 & 1.80 \\
\hline $\begin{array}{l}\text { Violence at } \\
\text { street }\end{array}$ & & & 0.18 & $3.17^{* * *}$ \\
\hline Violence at & & & & \\
\hline home & & & 0.23 & $4.73^{* * *}$ \\
\hline Violence at tv & & & -0.04 & -0.84 \\
\hline Violence at v.g. & & & 0.00 & 0.14 \\
\hline $\begin{array}{l}\text { Violence justifi- } \\
\text { cation }\end{array}$ & & & 0.18 & $3.85^{* * *}$ \\
\hline Female & 0.322 & $23.65^{* * *}$ & & \\
\hline Family status & & & -0.01 & -0.25 \\
\hline
\end{tabular}




$\begin{array}{lcc}\text { Violence at high } & 0.01 & 0.34 \\ \text { school } & & 3.044^{* * *} \\ \text { Violence at } & 0.17 & 5.61^{* * *} \\ \quad \text { street } & & 1.67 \\ \quad \text { Violence at } & 0.28 & -3.07^{* * *} \\ \quad \text { home } & 0.08 & 0.616^{* * *} \\ \quad \text { Violence at tv } & -0.14 & \end{array}$

Table 2. CPV towards father as a function of participant's sex.

\begin{tabular}{|c|c|c|c|c|}
\hline Variable & Adjusted $R^{2}$ & $F \Delta$ & Beta & $t$ \\
\hline Male & 0.192 & $14.82^{* * *}$ & & \\
\hline Sex & & & -0.03 & -0.67 \\
\hline $\begin{array}{l}\text { Violence at h. } \\
\text { school }\end{array}$ & & & 0.08 & 1.40 \\
\hline $\begin{array}{l}\text { Violence at } \\
\text { street }\end{array}$ & & & 0.20 & $3.47^{* * *}$ \\
\hline Violence at & & & & \\
\hline home & & & 0.19 & $3.77^{* * *}$ \\
\hline Violence at $\mathrm{tv}$ & & & -0.04 & -0.87 \\
\hline Violence at v.g. & & & -0.00 & -0.15 \\
\hline $\begin{array}{l}\text { Violence justifi- } \\
\text { cation }\end{array}$ & & & 0.15 & $3.18^{* * *}$ \\
\hline Female & 0.188 & $11.83^{* * *}$ & & \\
\hline Sex & & & -0.08 & -1.67 \\
\hline $\begin{array}{l}\text { Violence at h. } \\
\text { school }\end{array}$ & & & 0.03 & 0.65 \\
\hline Violence at street & & & 0.07 & 1.15 \\
\hline Violence at home & & & 0.21 & $3.87^{* * *}$ \\
\hline Violence at tv & & & 0.06 & 1.19 \\
\hline Violence at v.g. & & & -0.08 & -1.61 \\
\hline $\begin{array}{l}\text { Violence justifica- } \\
\text { tion }\end{array}$ & & & 0.27 & $5.27^{* * *}$ \\
\hline
\end{tabular}
${ }^{*} p<0.05 .{ }^{* *} p<0.01 .{ }^{* *} p<0.001$.

With regard to the role of the type of family (table 3), in the case of non-divorced families there was a significant relationship with exposition to violence at street, home and an inverse relationship with videogames, as well as with violence justification. In the case of divorced families the only significant variable was violence justification. Finally, with regard to violence towards father (table 4), there was a significant relationship with violence at high school, street and home, along with violence justification in the case of non-divorced families, as well as violence at street and violence justification in the case of divorced families.

Table 3. CPV towards mother as a function of family status.

\begin{tabular}{|c|c|c|c|c|}
\hline Variable & Adjusted $R^{2}$ & $F \Delta$ & Beta & $t$ \\
\hline Intact family & 0.314 & $38.99^{* * *}$ & & \\
\hline Sex & & & 0.31 & 0.75 \\
\hline $\begin{array}{l}\text { Violence at } \mathrm{h} \text {. } \\
\text { school }\end{array}$ & & & 0.32 & 0.74 \\
\hline
\end{tabular}




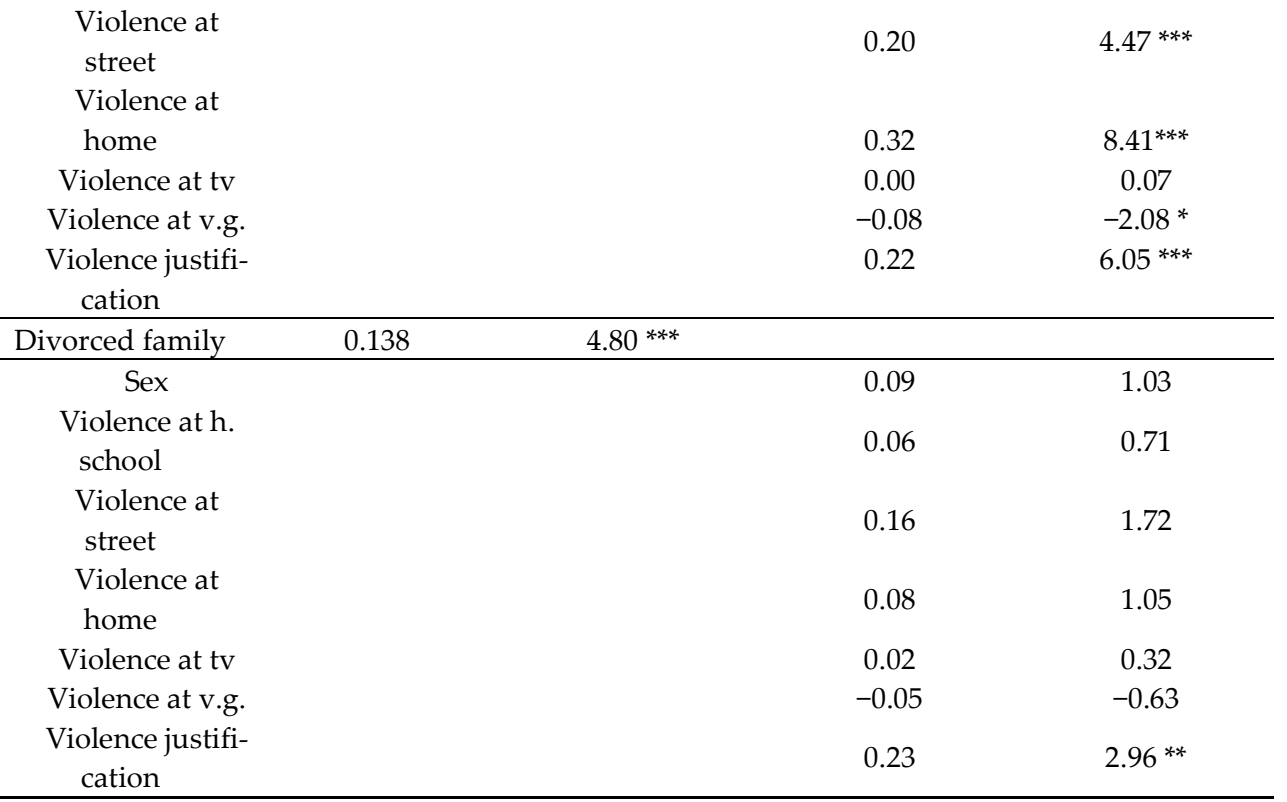

${ }^{*} p<0.05 .{ }^{* *} p<0.01 .{ }^{* * *} p<0.001$.

Table 4. CPV towards father as a function of family status.

\begin{tabular}{|c|c|c|c|c|}
\hline Variable & Adjusted $R^{2}$ & $F \Delta$ & Beta & $\bar{t}$ \\
\hline Intact family & 0.204 & $22.11^{* * *}$ & & \\
\hline Sex & & & -0.01 & -0.25 \\
\hline $\begin{array}{l}\text { Violence at h. } \\
\text { school }\end{array}$ & & & 0.09 & $1.98 *$ \\
\hline $\begin{array}{l}\text { Violence at } \\
\text { street }\end{array}$ & & & 0.11 & $2.25 *$ \\
\hline Violence at & & & & \\
\hline home & & & 22 & $5.48^{* * *}$ \\
\hline Violence at $t v$ & & & 0.03 & 0.82 \\
\hline Violence at v.g. & & & -0.06 & -1.41 \\
\hline $\begin{array}{l}\text { Violence justifi- } \\
\text { cation }\end{array}$ & & & 0.20 & $4.98^{* * *}$ \\
\hline Divorced family & 0.158 & $5.25^{* * *}$ & & \\
\hline Sex & & & -0.00 & -0.07 \\
\hline $\begin{array}{l}\text { Violence at h. } \\
\text { school }\end{array}$ & & & -0.03 & -0.38 \\
\hline $\begin{array}{l}\text { Violence at } \\
\text { street }\end{array}$ & & & 0.32 & $3.31^{* * *}$ \\
\hline $\begin{array}{l}\text { Violence at } \\
\text { home }\end{array}$ & & & 0.09 & 1.10 \\
\hline Violence at $t v$ & & & -0.14 & -1.69 \\
\hline Violence at v.g. & & & -0.01 & -0.12 \\
\hline $\begin{array}{l}\text { Violence justifi- } \\
\text { cation }\end{array}$ & & & 0.23 & $2.84^{* *}$ \\
\hline
\end{tabular}

\section{Discussion}


The present study provides data that can contribute to clarify the relationships between the role of participant sex and family status in the relationship of exposition to violence and violence justification with CPV. In relation to exposition to violence, strong relationship with CPV were found in the case of home, street, high school and video games. However, important differences were found as a function of participants' sex and family status. For example, there was a direct relationship between exposition to violence at high school and CPV, but only in the case of non-divorced parents. Calvete \& Orue [20] confirm the exposition to violence effect, where most adolescents that committed CPV were previously exposed to violence at home. In relation to this result, Martin and Hernandez [21] studied the difference between adolescents who committed violent and nonviolent behavior, finding that the first group were more exposed to violence at street than the second one.

In relation to violent video games, we found an inverse relationship with CPV towards mother in the case of non-divorced parents. The study of Jones [22] found that videogames decrease aggressive behavior. However, some studies have shown different results, finding that violent behavior increases as a consequence of video games exposure [23] [24]. Regarding the sex of the participant, it's interesting to point out the fact that violent video games were connected to CPV towards mother in the case of female participants.

As in the case of violence justification, results are different depending on the family status and participants'sex. In this regard, Calvete and Orue [25] found a direct relationship, concluding that justification is a severe cognitive schema which influences violent behavior. Moreover, in our study, we found that if the aggressive behavior was committed to the mother the relationship between violence justification and CPV was inverse and, if those behaviors were committed to the father, the relationship between these variables was direct.

The present study shows the role of participant sex and family status the relationship of exposition to violence and violence justification with CPV violence. These findings indicate the importance of taking into account those variables in preventing violence towards parents.

Author Contributions: Conceptualization, M.J., A.R., and D.C.; methodology, M.J., A.R., and D.C.; software, D.C.; formal analysis, D.C.; investigation, M.J., A.R., and D.C.; data curation, M.J. and A.R.; writing-original draft preparation, M.J., A.R., and D.C.; writing-review and editing, D.C.; supervision, D.C.; project administration, D.C. All authors have read and agreed to the published version of the manuscript.

Funding: This research received no external funding.

Conflicts of Interest: The authors declare no conflict of interest.

\section{References}

1. Pereira, R.; Loinaz, I.; Del Hoyo-Bilbao, J.; Arrospide, J.; Bertino, L.; Calvo, A.; Gutiérrez, M.M. Propuesta de definición de violencia filio-parental: consenso de la sociedad española para el estudio de la violencia filio-parental (SEVIFIP). Papeles del Psicol. 2017, 38, 216-223. https://doi.org/10.23923/pap.psicol2017.2839

2. Gallagher, E. Children's violence to parents: a critical literature review. Melbourne: Monash University. 2008.

3. Del Hoyo-Bilbao, J.; Gámez-Guadix, M.; Calvete, E. Corporal punishment by parents and child-to-parent aggression in Spanish adolescents. An. de Psicol. 2018, 34, 108- 116. http://dx.doi.org/10.6018/analesps.34.1.259601.

4. Gulati, G.; Kelly, B. D. Domestic violence against women and the COVID-19 pandemic: What is the role of psychiatry? Int. J. Law Psychiatry, 2020, 71, 101594. https://doi.org/10.1016/j.ijlp.2020.101594.

5. Condry, R.: Miles, C.; Brunton-Douglas, T.; Oladapo, A. Experiences of child and adolescent to parent violence in the covid-19 pandemic. University of Oxford. 2020.

6. Calvete, E; Orue, I.; Gónzalez-Cabrera, J. Violencia filio parental: comparando lo que informan los adolescentes y sus progenitores. Rev. Psicol. Clín. niños adolesc. 2017, 4, 9-15.

7. Ibabe, I.; Jaureguizar, J. ¿Hasta qué punto la violencia filio- parental es bidireccional? [Is child to parent violence bi- directional? An. de Psicol. 2011, 27, 265-277.

8. Ibabe, I. Family predictors of child-to-parent violence: the role of family discipline. An. De Psicol. 2015, 31, 615-625. http://dx.doi.org/10.6018/analesps.31.2.174701. 
9. Gámez-Guadix, M.; Calvete, E. Violencia filioparental y su asociación con la exposición a la violencia marital y la agresión de padres a hijos. Psicothema 2012, 24, 277- 283.

10. Calvete, E.; Orue, I.; Bertino, L.; Gonzalez, Z.; Montes, Y.; Padilla, P.; Pereira, R. Child-to-parent violence in adolescents: the perspectives of the parents, children, and professionals in a sample of Spanish focus group participants. J. Fam. Violence 2014, 29, 343-352.

11. Greitemeyer, T.; Osswald, S. (2014). Effects of prosocial video games on prosocial behaviour. J. Pers. Soc. Psychol. 2014, 98, 211221.

12. Jiménez, S. El abuso de las tecnologías de la información y la comunicación (TICs) como factor de riesgo en la Violencia FilioParental. En Respuestas e intervenciones educativas en una sociedad diversa; El Homrani, M., Ávalos, I., Báez, D.E., Coord.; Granada, España: Comares. 2017, 304-312.

13. Pellegrini, S. And how does that make you feel? A Psychological approach to a classic game studies debate - Violent Video Games and Aggression. Press Start 2019, 4, 69-81.

14. Calvete, E. Justification of violence and grandiosity schemas as predictors of antisocial behavior in adolescents. J. Abnorm. Child Psychol. 2008, 36, 1083-1095.

15. Orue, I.; Calvete, E. La justificación de la violencia como mediador de la relación entre la exposición a la violencia y la conducta agresiva en infancia. Psicothema 2012, 24, 42-47.

16. Calvete, E., Gámez-Guadix, M., Orue, I., González-Diez, Z., López de Arroyabe, E., Sampedro, R., Pereira, R., Zubizarreta, A., Borrajo, E. The Adolescent Child-to-Parent Aggression Questionnaire: An examination of aggresion against parents in Spanish adolescents. J. Adolesc. 2013, 36, 1077-1081.

17. Calvete, E., Orue, I. Cognitive schemas and aggresive behavior in adolescents: The mediating role of social information processing. Span J. Psychol. 2010, 1, 190-201.

18. Cardeñoso, O., Calvete, E. Desarrollo del Inventario de Creencias Irracionales para adolescentes. Psicol Conductual. 2004, 12, 289-304.

19. Cohen, J.; Cohen, P. Applied multiple regression/correlation analysis for the behavioral sciences. Hillsdale, NJ: Lawrence Erlbaum Associates. 1983.

20. Calvete, E, Orue I. The impact of violence exposure on aggresive behavior through social informaton processing in adolescents. Am J. Orthopsychiatry, 2011, 81 (1), 38.

21. Martin, A.M., Hernández, A. Exposición a la violencia y violencia filioparental en menores infractores y reclusos. Colección Psicología y Ley, 2020.

22. Jones, G. The effects of violence in video games on individual levels of hostility in young adults, 2018.

23. Romanchych, E.L. Violent video gaming, parent and child risk factors, and aggression in school-age children, University of Windsor, Canada. 2018.

24. Tear, M.J. Violent video games and social behaviour. University of Queensland, Australia. 2015.

25. Orue, I., Calvete, E. Elaboración y validación de un cuestionario para medir la exposición a la violencia en infancia y adolescencia. Rev Int Psicol Ter Psicol, 2010, 10, 279-292. 